\title{
Physical factors and their influence on fish species composition in Asa Lake, Ilorin, Nigeria
}

\author{
P.A. Araoye \\ Department of Biological Sciences, Benue State University Makurdi, Nigeria; araoyepa@yahoo.com
}

Received 08-II-2008. C Corrected 20-VI-2008. Accepted 27-VII-2008.

\begin{abstract}
The effect of physical factors on fish species composition was studied during 12 months in Asa Lake, Nigeria. Fish and water samples were collected bimonthly (March 2003 to February 2004) in the morning. Fish samples were caught with gill nets set at the surface and bottom habitats. There were 11 fish families and 21 species. Osteoglossidae, Anabantidae, Channidae, Schilbedae and Cyprinidae were rare and occurred seasonally in fishermen catches, while Mormyridae, Cichlidae, Mochokidae, Characidae, Bagridae and Clariidae showed less variation and were more common. Characidae and Cichlidae were the most abundant (23.0 and 18.6\% respectively) while Osteoglossidae, Channidae and Anabantidae were the least (1.7, 2.1 and 2.3\% respectively). Clariidae and Mormyridae had the highest weight with $16.0 \%$ and $12.3 \%$ respectively, while Anabantidae had the lowest (3.4\%). Surface water temperatures were generally higher than air temperatures during the afternoon, except from January to March when air temperatures were high $\left(28.1\right.$ to $\left.28.7^{\circ} \mathrm{C}\right)$ due to low relative humidity (39 to $70 \%$ ). In the morning, surface water temperatures $\left(25.5\right.$ to $\left.26.3{ }^{\circ} \mathrm{C}\right)$ became higher than air temperatures ( 25.2 to $26.0^{\circ} \mathrm{C}$ ) from May to December, when relative humidity values were also high $(50$ to $88 \%$ ). The differences between surface and bottom water temperatures was generally higher $\left(0.7\right.$ to $\left.3.1^{\circ} \mathrm{C} ; \mathrm{P}<0.05\right)$ in the afternoon $\left(0.2\right.$ to $\left.0.8^{\circ} \mathrm{C}\right)$ due to sunlight. Temperature differences in the surface and bottom waters were usually higher during the dry season $(\mathrm{P}<0.05)$, for similar reasons. Captures were higher in the dry season when the fish concentrated in the warmer, steadier and scarcer water. Minimal and maximal temperatures were different for surface and bottom waters $(\mathrm{P}<0.05)$. However, there were no marked variations in temperature patterns or species distribution. Rev. Biol. Trop. 57 (1-2): 167-175. Epub 2009 June 30.
\end{abstract}

Key words: fish species composition, air temperature, water temperature, Asa Lake, Ilorin, Nigeria.

The effect of temperature on the distribution and physiological processes of the flora and fauna of the aquatic environment cannot be over emphasized. In fishes, temperature is an important external factor in the early life stages because it has a direct influence on the timing of ontogenetic events (Bagenal, 1978). The demand for oxygen increases continuously during embryogenesis and is influenced by temperature, therefore both temperature and oxygen supply may accelerate or retard the morphogenetic process of development (Balon, 1975; Bagenal, 1978). Movement of plankton and fish is influenced by water temperature and this is usually more pronounced especially in the temperate regions where there is wide variation in the seasonal changes of temperature.

In Jebba lake, Nigeria, the changes in temperature and other biological factors including succession were responsible for the elimination of some aquatic plants (Adeniji et al., 1984). Seasonal changes in temperature reflect on the growth pattern in fishes. This information has been used in the study of distribution, age and growth of fishes by Fagade (1974), Van Der Waal and Schoonbee (1975), Ikisemiju (1976), Araoye, (2002). Temperature affects directly or indirectly other limnological parameters such as transparency, viscosity, dissolved gases, $\mathrm{pH}$, Total dissolve solids, conductivity (Whitney, 
1942); all of which constitute the very important limnological parameters that form the basis for an enlightened fisheries and water resources management.

There is literature on the fish species distribution and the temperature pattern of some Nigerian inland waters; including Hill and Webb (1958) on Lagoon waters; Imevbore (1975) on Kainji Lake; Adebisi (1981) on Upper Ogun River and Adeniji (1991) on Jebba Lake; Araoye and Owolabi (2005) on Kampe (Omi) dam. Twelve fish families comprising of seventeen fish species were recorded in Kampe (Omi) dam, Nigeria (Araoye and Owolabi, 2005). This work which also examines the fish species composition with the temperature regime of Asa Lake in Ilorin is most recent in the history of the dam. The lake now constitutes another source of fresh water fish supply to Ilorin and environs to complement the supply from other sources including Kainji, Jebba and Moro lakes.

\section{MATERIALS AND METHODS}

The lake is located at about 5 kilometers south of Ilorin across river Asa. It is about 302 hectares in surface area (Ita et al. 1985) The fish sampling sites, which were usually selected by chance by fishermen, covered Odore, Laduba and Afon all along the lake from the dam site to the river source. Odore was close to the dam where maximum depth at high water levels did not exceed 14 meters. Laduba and Afon are located near the river source and have a depth of 11 meters at high water levels. These sites were reached through a paddled canoe by the six selected fishermen (two per site) during the sampling trips.

The fish and water samples were collected bimonthly for twelve months (March 2003 to February 2004) in the morning hours between 06.00 and 07.00 a.m. and the afternoon hours between 12.00 and 1.00 p.m. Fish samples were caught with the gill nets (range 5.08 to $10.16 \mathrm{~cm}$ mesh sizes in a fleet) that were set at the surface and bottom habitats as described by Araoye (1999). They were identified into families and species as described by Reed, et al. (1967) and Olaosebikan and Raji (1998). Water samples were collected from the surface and bottom habitats using the Kemmer water sampler attached to a graduated nylon rope. Samples were taken randomly from three places in each of the sampling sites to determine the mean temperatures. Water temperature was taken to the nearest $0.1{ }^{\circ} \mathrm{C}$ using a thermometer with a range of $0{ }^{\circ} \mathrm{C}$ to $100{ }^{\circ} \mathrm{C}$. Transparency levels were also determined using secchi disc with a calibrated rope attached. This was lowered into the water until it disappeared and then brought up gently until it appeared. The mean of these two depths was recorded as the depth of the transparency level. Monthly mean rainfall, relative humidity (R.H.) and air temperatures around the dam were obtained from Ilorin International Airport that was just about two kilometers away. Monthly water levels were also recorded from the water level gauge installed at the dam by the state utility board. The data were subjected to statistical analysis including t-test and correlation coefficient.

\section{RESULTS}

There were eleven fish families comprising of twenty one species. These include families Osteoglossidae, Anabantidae, Chanidae, Schilbedae, Cyprinidae, Mormyridae, Cichlidae, Mochokidae, Characidae, Bagridae and Clariidae (Table 1). The families Osteoglossidae, Anabantidae, Chanidae, Schilbedae and Cyprinidae were less abundant and showed seasonal variations in the catches by the fishermen along the lake while Mormyridae, Cichlidae, Mochokidae, Characidae, Bagridae and Clariidae showed less variation and were more common in the catches (Table 5). The families Characidae and Cichlidae were the most abundant in number (23.0 and 18.6\%) respectively while Osteoglossidae, Channidae and Anabantidae were the least (1.7, 2.1 and $2.3 \%$ ) respectively (Fig. 1). In terms of weight the family Mormyridae was highest constituting $16.4 \%$ while Anabantidae was lowest constituting $3.54 \%$ (Fig. 1). Mean surface water 
TABLE 1

Fish families and species found in Asa lake, Nigeria (March 2002 to February 2003)

FAMILIES

Osteoglossidae

Mormyridae

Characidae

Cyprinidae

Bagridae

Schilbedae

Clariidae

Mochokidae

Ciclidae

Anabantidae

Channidae

\section{SPECIES}

Heterotis niloticus (Cuvier)

Mormyrus rume (Cuvier \& Valenciennes)

Petrocephalus bovel (Cuviet \& Valenciennes)

Mormyrus delicious (Leech)

Gnathonemus cyprinoides (Linne)

Alestes nurse(Rupel)

Labeo senegalences (Boulenger)

Barbus occidentalis (Bpulenger)

Chrysichthys nigridigitatus (Lacepede)

Auchenoglanis occidentalis (Cuvier \& Valenciennes)

Schilbe mystus (Linnes)

Clarias lazera ((Cuvier \& Valenciennes)

Clarias anguillaris (Linnaeus)

Synodontis schall (Bloch \& Schneider)

Synodontis gambiensis (Boulenger)

Hemicromis fasciatus (Peters)

Tilapia zilli (Gervais)

Oreochromis niloticus (Linnaeus)

Sarotherodon galilaeus (Artedi)

Ctenopoma kingsleyae (Gunther)

Channa obscura (Gunther)

\section{CATEGORY OF ABUNDANCE \\ Rare}

Abundant

Common

Abundant

Common

Abundant

Rare

Common

Abundant

Abundant

Rare

Common

Common

Abundant

Common

Abundant

Abundant

Abundant

Abundant

Rare

Rare

Rare: $\quad<10$ per hundred specimens

Common: 10 to 50 per hundred specimens

Abundant: $>50$ per hundred specimens

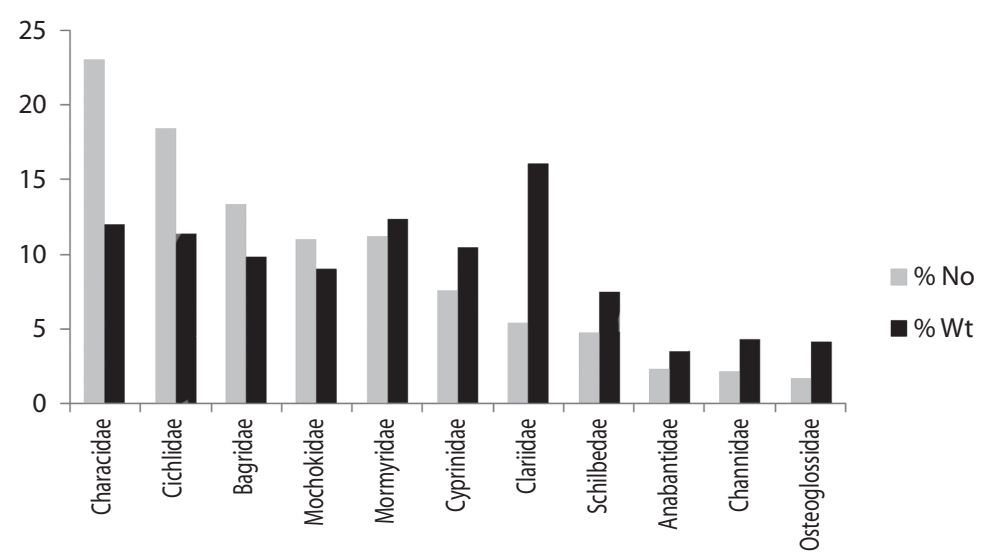

Fig. 1. Fish families and its composition in weight (Wt) and numbers (No), Asa Lake, Nigeria (March 2002 to February 2003). 
temperatures were generally higher $(26.0$ to $27.0^{\circ} \mathrm{C}$ ) than air temperatures $\left(25.9\right.$ to $28.7^{\circ} \mathrm{C}$ ) in the afternoon hours except for few months (January to March) when mean air temperatures were above $28{ }^{\circ} \mathrm{C}$. Air and surface water temperatures were almost uniform in the month of October / November but most peculiarly in the morning hours. Monthly variations of water temperatures (surface and bottom) are shown in Tables 2 and 3. The maximum depth that could be reached at low water levels was 11 meters. The temperatures of the surface and bottom waters were significantly different ( $P$ $<0.05$ ) during the morning hours of the dry

TABLE 2

Mean monthly value of water temperatures, meteorological parameters, and transparency levels in Asa lake, March 2002 - February 2003 (Time: 12.00 noon-1.00 p.m.)

$\begin{array}{lcccccccc}\text { Month } & \begin{array}{c}\text { Surface water } \\ \left(\mathrm{T}{ }^{\circ} \mathrm{C}\right)\end{array} & \begin{array}{c}\text { Bottom water } \\ \left(\mathrm{T}{ }^{\circ} \mathrm{C}\right)\end{array} & \begin{array}{c}\text { Temperature } \\ \text { difference }\left({ }^{\circ} \mathrm{C}\right)\end{array} & \begin{array}{c}\text { Air Temp. } \\ \left({ }^{\circ} \mathrm{C}\right)\end{array} & \begin{array}{c}\text { RH } \\ (\%)\end{array} & \begin{array}{c}\text { RF } \\ (\mathrm{cm})\end{array} & \begin{array}{c}\text { Water level } \\ (\mathrm{m})\end{array} & \begin{array}{c}\text { Transp. level } \\ (\mathrm{cm})\end{array} \\ \text { Mar. } & 28.9 & 26.3 & 2.6 & 33.6 & 70 & 2.8 & 11.1 & 1.7 \\ \text { Apr. } & 28.8 & 26.2 & 2.6 & 31.5 & 75 & 1.1 & 11.1 & 1.8 \\ \text { May. } & 28.9 & 26.1 & 2.8 & 31.5 & 74 & 4.6 & 11.4 & 1.6 \\ \text { Jun. } & 28.7 & 26.1 & 2.6 & 29.4 & 79 & 9.7 & 11.9 & 1.5 \\ \text { Jul. } & 28.3 & 26.0 & 2.3 & 27.6 & 86 & 16.0 & 12.2 & 1.4 \\ \text { Aug. } & 29.0 & 25.9 & 3.1 & 26.7 & 88 & 25.8 & 12.4 & 1.0 \\ \text { Sept. } & 27.5 & 26.7 & 0.8 & 28.0 & 84 & 9.3 & 12.5 & 0.6 \\ \text { Oct. } & 27.5 & 26.5 & 1.0 & 29.2 & 85 & 15.5 & 12.4 & 0.6 \\ \text { Nov. } & 28.4 & 26.3 & 2.1 & 32.4 & 76 & 5.9 & 12.0 & 0.9 \\ \text { Dec. } & 28.4 & 26.3 & 2.1 & 31.9 & 50 & 0.0 & 11.9 & 1.3 \\ \text { Jan. } & 28.5 & 25.5 & 3.0 & 28.4 & 39 & 0.7 & 11.4 & 1.5 \\ \text { Feb. } & 28.7 & 25.7 & 3.0 & 33.3 & 57 & 0.0 & 11.2 & 1.7\end{array}$

TABLE 3

Mean monthly value of water temperatures, meteorological parameters, and transparency levels in Asa lake, March 2002 - February 2003 (Time: 06.00 - 07.00 a.m.)

$\begin{array}{lcccccc}\text { Month } & \begin{array}{c}\text { Surface water } \\ \left(\mathrm{T}^{\circ} \mathrm{C}\right)\end{array} & \begin{array}{c}\text { Bottom water } \\ \left(\mathrm{T}{ }^{\circ} \mathrm{C}\right)\end{array} & \begin{array}{c}\text { Temperature } \\ \text { difference }\left({ }^{\circ} \mathrm{C}\right)\end{array} & \begin{array}{c}\text { RF } \\ (\mathrm{cm})\end{array} & \begin{array}{c}\text { Water } \\ \text { level }(\mathrm{m})\end{array} & \begin{array}{c}\text { Transp. } \\ \text { level }(\mathrm{cm})\end{array} \\ \text { Mar } & 27.3 & 26.7 & 0.6 & 2.8 & 11.1 & 1.7 \\ \text { Apr } & 27.4 & 26.6 & 0.8 & 1.1 & 11.1 & 1.7 \\ \text { May } & 27.3 & 26.6 & 0.7 & 4.6 & 11.4 & 1.6 \\ \text { Jun } & 27.0 & 26.3 & 0.7 & 9.7 & 11.9 & 1.5 \\ \text { Jul } & 27.0 & 26.6 & 0.4 & 16.0 & 12.2 & 1.3 \\ \text { Aug } & 27.0 & 26.6 & 0.4 & 25.8 & 12.4 & 0.6 \\ \text { Sept } & 26.8 & 26.4 & 0.4 & 9.3 & 12.5 & 0.5 \\ \text { Oct } & 26.4 & 26.2 & 0.2 & 15.5 & 12.4 & 0.4 \\ \text { Nov } & 26.5 & 25.3 & 0.2 & 5.9 & 12.0 & 1.2 \\ \text { Dec } & 26.5 & 25.2 & 0.2 & 0.0 & 11.9 & 1.3 \\ \text { Jan } & 27.4 & 26.7 & 0.7 & 7.2 & 11.4 & 1.2 \\ \text { Feb } & 27.4 & 26.8 & 0.6 & 0.0 & 1.2 & 1.7\end{array}$


seasons (December to April). Air and water temperatures that were recorded in the morning hours were lower than those recorded in the afternoon hours. Monthly variation of relative humidity, rainfall, water and transparency levels is also presented in Tables 2 and 3. There were little or no rainfalls in from December to February corresponding with the periods of higher catches. Relative humidity was high as from May to October and low in December to March (Table 2).

The mean transparency levels that were usually high at dry season when fish catch were usually higher dropped as from August to October corresponding with the period of flood around the lake, during which air and water temperatures were relatively low. Transparency levels in the morning and afternoon hours did not show any remarkable variation except in October / November when transparency levels were slightly lower in the morning hours (mean $=0.4 \mathrm{~m}$ ) Transparency and water levels were negatively correlated (-0.79). Similarly water temperatures and relative humidity were negatively correlated (-0.42) but air and water temperatures (Table 4 ) were positively correlated
(0.52). There were no marked variations in the meteorological and the temperature profile along the three sampling sites.

\section{DISCUSSION}

The relatively low fish species composition in Asa lake compared with Kainji dam in Nigeria can be attributed to the relatively small size of Asa dam. Willoughby (1974) recorded 16 species for the genus Synodontis alone in Kainji lake whereas only two species, $S$. schall and $S$. gambiences were recorded in this report for Asa lake. The abundance of Citharinidae, Distichodontidae, Mormyridae and the genus Synodontis shortly after the impoundment of Kainji dam was attributed to successful spawning and the presence of an unlimited food supply from the decay of the flooded vegetation which in turn encouraged rapid multiplication of insect diets for several fish species (Banks et al., 1965; Ita , 1973). However by 1970 there had been a drastic decrease in number of these species partly due reduction of food supply (Balogun, 1986). The paucity of the families Osteoglossidae, Anabantidae, Channidae,

TABLE 4

Correlation coefficient ${ }^{\circledR}$ values amongst temperatures, rainfall, water levels, relative humidity and transparency in Asa lake (Time: 6.00 a.m. and 1.00 p.m.)

\begin{tabular}{|c|c|c|c|c|c|c|c|c|}
\hline Rainfall & $\begin{array}{l}\text { Water } \\
\text { levels }\end{array}$ & $\begin{array}{l}\text { Air Temp. } \\
6.00 \mathrm{am}\end{array}$ & $\begin{array}{c}\text { Air Temp. } \\
1.00 \mathrm{pm}\end{array}$ & $\begin{array}{l}\text { Water Temp. } \\
\quad 6.00 \mathrm{am}\end{array}$ & $\begin{array}{c}\text { Water Temp. } \\
1.00 \mathrm{pm}\end{array}$ & $\begin{array}{l}\text { R.H. } \\
6.00 \mathrm{am}\end{array}$ & $\begin{array}{c}\text { R.H. } \\
1.00 \mathrm{pm}\end{array}$ & Transp. \\
\hline Water levels & $0.54 *$ & & & & & & & \\
\hline $\begin{array}{l}\text { Air temp. } \\
(6.00 \mathrm{am})\end{array}$ & -0.41 & -0.42 & & & & & & \\
\hline $\begin{array}{l}\text { Air temp. } \\
(1.00 \mathrm{pm})\end{array}$ & -0.57 & -0.23 & -0.34 & & & & & \\
\hline $\begin{array}{l}\text { Water temp. } \\
(6.00 \mathrm{am})\end{array}$ & -0.23 & 0.22 & 0.37 & $0.52^{*}$ & & & & \\
\hline $\begin{array}{l}\text { Water temp. } \\
(1.00 \mathrm{pm})\end{array}$ & 0.20 & 0.35 & 0.30 & $0.52^{*}$ & $0.52 *$ & & & \\
\hline R.H 6.00 am & $0.67^{*}$ & $0.50^{*}$ & $-0.65^{*}$ & $-0.57 *$ & $-0.53 *$ & -0.42 & & \\
\hline $\begin{array}{l}\text { R.H. } 1.00 \mathrm{pm} \\
0.47^{*}\end{array}$ & $0.50^{*}$ & $-0.52 *$ & $-0.53^{*}$ & -0.42 & $-0.50^{*}$ & 0.10 & & \\
\hline Transp. & -0.21 & $-0.79 *$ & 0.42 & $0.60^{*}$ & 0.33 & $0,55^{*}$ & $-0.60^{*}$ & $-0.51 *$ \\
\hline
\end{tabular}

\footnotetext{
* Significant correlation coefficient values $(\mathrm{P}<0.05)$.
} 


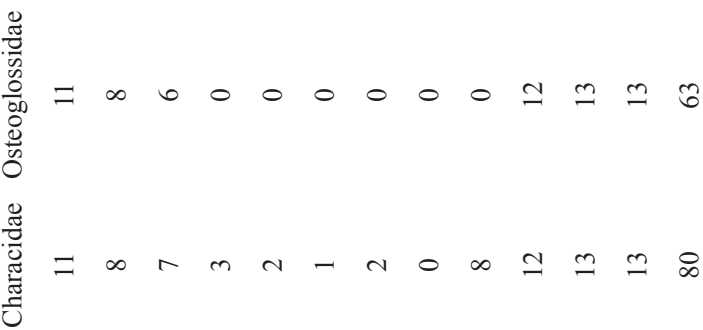

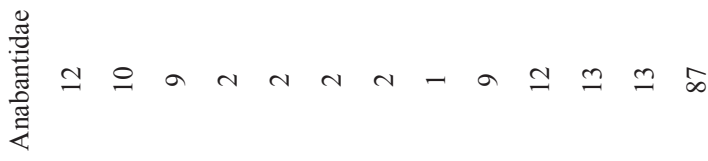

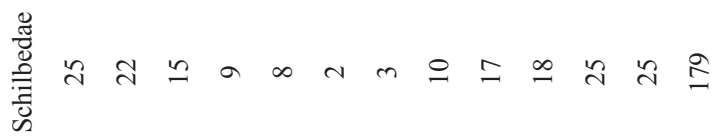

莺

:

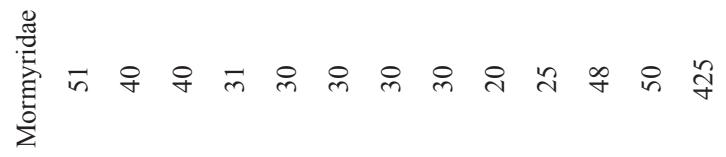

莺

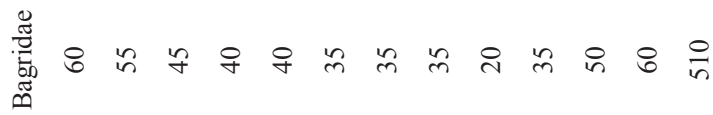

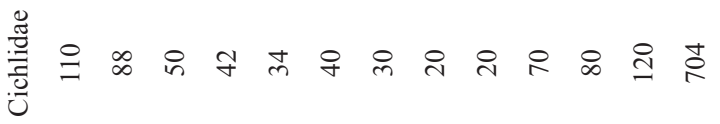

莺

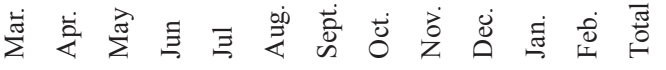


Schilbedae and Cyprinidae in the catch during the periods of floods and high water levels in Asa Lake is not unconnected with the prevailing lacustrine situation of the water body at this season. These fish families preferred the riverine environment hence they were restricted to the river course where the water levels were lower. Ita (1978) included Osteoglossidae, Channidae and Anabantidae among the fishes that diminished in abundance at the creation of Kainji dam while Araoye (1997) reported similar case in Asa dam. Large piscivorous fish species like Lates niloticus Gymnarchus niloticus were conspicuously reported absent in Asa lake due to its relatively small size compared with Kainji dam (Araoye, 1997) and river Benue (Fagade, 1983).

The positive correlation between air and surface water temperatures was due to the close contact between the air temperatures and the temperatures of the epilimnion (Parks, et al. 1975). Higher surface water temperatures in the afternoon hours were attributed to the less humid atmospheric air in the afternoon than the morning hours. Also low surface water temperatures during the wet seasons (May to October) were due to the more humid atmosphere and lower rate of evaporation. These changes in air and surface water temperatures were normal phenomena similar to the observations of Hill and Webb (1958) on the Lagos lagoon, Egborge (1970) on the River Osun, Imevbore (1975) on Kainji Lake and Adeniji (1991) on Jebba lake. The impact of flood around the lake in October and November enhanced the mixing of the surface waters resulting in temperature uniformity at the air - water interface in those months particularly in the morning hours. The flooding of the lake resulting in high water levels three months after the commencement of the rains caused mixing, turbidity and low transparency levels. Similar observations were reported in some other tropical lakes (Biswas, 1973; Olaniyan, 1975). Since heat is absorbed more rapidly at the surface of a water body, the warm surface waters are less dense than the cool bottom waters, hence body of water may stratify thermally (Boyd, 1979). In Asa Lake for example periodic stratification was reported as from January to August (Araoye, 1997). These periods corresponded with higher fish catches along the lake due to stability of water and low water levels resulting in higher concentration of fish. Hutchinson (1957), Odum (1971) and Wetzel (1975) described the classical pattern of thermal stratification of lakes. Distortion of the thermally stratified conditions in Asa Lake between August to November due to the mixing effect caused by high water current around the lake from the adjoining rivers after the rains did not only destabilize the water body but also the fishing gears particularly the gill nets. Hence the efficiency of these fishing gears may also be minimized. Mixing in some tropical lakes may be useful to fish because of the bottom nutrients that were brought up especially for non bottom dwelling fishes like Clupeids and detritus feeders such as Tilapia melanotheron (Fagade, 1974). Mixing in Asa Lake at the time of floods could also be of advantage to some fishes that fed on detritus such as Synodontis schall (Araoye and Jeje, 1999). It may also influence the spatial distribution of such fishes because the need to move towards the bottom habitat at this period to feed on detritus may not be required (Araoye, 1999). Therefore the bottom gill net may be less effective for catches at this season thus lowering total catch.

Fish mortality have been observed in some temperate fish ponds due to mixing or overturn resulting from temperature changes and it was explained that mixing of the large volumes of oxygen deficient hypolimnetic with waters of the epilimnion resulted in dissolved oxygen depletion (Boyd, 1979). Low transparency in August to October was due to turbidity of the lake at this period which is a usual occurrence in the tropical lakes. Water level was significantly correlated with the transparency. The negative value of ' $r$ ' is an indication that generally the transparency is low when water level is high and vice versa (Adebisi, 1981). It was noted that the maximum transparency $(3.0 \mathrm{~m})$ recorded in Kainji dam by Henderson (1975) was higher than what is now recorded for Asa dam $(1.8 \mathrm{~m})$. This indicates that the 
flood and turbidity were more pronounced in Asa Lake than in Kainji Lake probably due to the small size of Asa dam compared with Kainji dam which has a larger surface area of impounding the incoming floods. The relatively small size of Asa Lake was also responsible for the temperature similarities along the sampling sites. Hence the fish species distribution with respect to the temperatures along the lake exhibited no variation, unlike what was reported in Kainji Lake (Willoughby, 1974) and Jebba Lake (Adeniji, et al., 1984). The small size of this lake coupled with the low fish species composition should necessitate strict monitoring and regulation of fishing activities around the water body in order to sustain the fisheries potential. Araoye, 2007 recommended the enforcement of a more aggressive fishery laws along inland water bodies, suggesting the involvement of their local communities. The fisher folk and their communities must constitute themselves into surveillance groups along their lakes to fish out defaulters and non - registered fishermen for punishment according to the laws, while Government agencies concerned in the lake management should also provide monitoring aids and equipments to the monitoring groups along the water bodies in order to prevent the lake fisheries resources from a state of emergency.

\section{ACKNOWLEDGMENTS}

I am grateful to the fishermen in Asa Lake and the staff of the Meteorological Department of the Federal Secretariat, Ilorin Kwara State, Nigeria.

\section{RESUMEN}

Estudié la composición de especies de peces y las temperaturas durante 12 meses en el lago Asa, Nigeria. Recolecté muestras de peces y de agua bimestralmente en la mañana, de marzo 2003 a febrero 2004. Los peces (11 familias y 21 especies) fueron capturados con atarrayas en la superficie y el fondo. Osteoglossidae, Anabantidae, Channidae, Schilbedae y Cyprinidae fueron raras y aparecieron estacionalmente en las capturas de pescadores, mientras que Mormyridae, Cichlidae, Mochokidae, Characidae,
Bagridae y Clariidae mostraron menos variación y fueron más comunes. Las familias Characidae y Cichlidae fueron las más abundantes (23.0 y $18.6 \%$ respectivamente) mientras Osteoglossidae, Channidae y Anabantidae fueron las más escasas $(1.7,2.1$ y $2.3 \%$ respectivamente). Clariidae y Mormyridae tuvieron el peso más alto con $16.0 \%$ y $12.3 \%$ respectivamente, mientras que Anabantidae fue la más baja, con 3.4\%. La estación seca correspondió con capturas altas al concentrarse los peces en el agua más cálida, estable y escasa. Las temperaturas mínimas y máximas fueron diferentes en las aguas superficiales y del fondo $(\mathrm{P}<0.05)$. No obstante, no hubo variaciones marcadas en el patrón de temperatura y distribución de peces.

Palabras clave: composición de especies de peces, temperatura del agua, temperatura del aire, lago Asa, Ilorin, Nigeria.

\section{REFERENCES}

Adebisi, A.A. 1981. The physico-chemical hydrology of a tropical seasonal river-upper Ogun river. Hydrobiologia 79: 157-165.

Adeniji, H.A. 1991. Limnology and biological production in the pelagic zone of Jebba lake, Nigeria. Ph.D. Thesis, University of Ibadan, Ibadan, Nigeria.

Adeniji, H.A., I.G. Mbagwu \& F. Ibikunle. 1984. Study on some aspects of the water quality of the new Jebba lake and its effect on the lake fisheries. KLRI. Annual Report. p. 25-32.

Araoye, P.A. 1997. Bio-ecology of a Mochokid, Synodontis schall (Bloch and Schneider 1801) in Asa lake Ilorin, Nigeria. Ph.D. Thesis, University of Ibadan, Ibadan, Nigeria.

Araoye, P.A. 1999. Spatio-temporal distribution of Synodontis schall (Teleotei: Mochokidae) in Asa lake Ilorin, Nigeria. Rev. Biol. Trop. 47: 1061-1066.

Araoye, P.A. \& C.Y. Jeje. 1999. The diet of Synodontis schall (Bloch \& Schneider 1801) in Asa dam Ilorin, Nigeria. Nig. J. Sci. 33: 67-76.

Araoye, P.A. 2002. Age and growth studies of Synodontis schall (Teleotei: Mochokidae) in the environment of Asa lake Ilorin, Nigeria. Nig. J. Pure \& Appl. Sci. 17: $1235-1244$.

Araoye, P.A. and O. Owolabi. 2005. Some changes in the animal and fish species composition due to the construction of Kampe (Omi) dam and irrigation project in Kogi State, Nigeria. Nig. J. Pure \& Appl. Sci. 20: 1781-1789. 
Araoye, P.A. 2007. Conservation needs for the fisheries resources of Kampe (Omi) dam and irrigation project in Kogi State, Nigeria. Nig. J. Fish. 4: 75-83.

Bagenal, T.B. 1978. Aspects of fish fecundity, p. 75-95. In S.D. Gerking (ed.), Ecology of freshwater fish production. Blackwell Scientific, Oxford, England.

Balogun, J.K. 1986. Fish distribution in Kainji Lake, Nigeria. J. Fish. Biol. 29: 489-498.

Balon, E.K. 1975. Reproduction guilds in fishes: A proposal and definition. J. Fish. Res. Bd. Can. 32: 821-861.

Banks, J.W., M.J. Holden \& R.H. Mc Connell. 1965. The first scientific report of the Kainji biological research team. E. White. p. 21-42.

Biswas, S.O. 1973. Limnological observations during the early formation of Volta lake in Ghana. Geophys. Monogr. 17: 121-128.

Boyd, C.E. 1979. Water quality in warm water fish ponds. Craftmaster,Opelika, Alabama, USA. 353 p.

Egborge, A,B. 1970. The hydrology and plankton of Asejire lake. Ph.D. Thesis, University of Ibadan, Ibadan, Nigeria.

Fagade, S.O. 1974. Age determination in Tilapia melanotheron in Lagos lagoon, Nigeria with discussion on the environmental and physiological basis of growthmarkings in the tropics, p. 71-77. In T.B. Bagenal (ed.). Ageing of fish. Unwin, Old Woking, Surrey, England.

Fagade, S.O. 1983. Food and feeding habits of the fishes of Lower River Benue, Nigeria. Bull. IFAN45 Ser. A: $316-314$.

Henderson, H.F. 1975. Thermal stratification of Kainji lake. In A.M.A. Imevbore \& O.S. Adegoke (eds.) Ecology of lake Kainji. The transition from river to lake. University of Ife. Ife, Nigeria. Webb. 1958. The topography and physical features of Lagos Harbour and Lagos Lagoon. Phil. Trans. Roy. Soc. Lond. Ser. B. $683: 319-333$.

Hutchison, C.E. 1957. A treatise of limnology. Vol. 1 Geography, Physics and Chemistry. Wiley, New York, New York, USA.

Ikusemiju, K. 1976. Distribution, reproduction and growth of the cat fish Chrysichthys walkeri (Gunter) in Lekki lagoon, Nigeria. J. Fish. Biol. 8: 453-458.

Imevbore, A.M.A.1975. Ecology of the newly formed Kainji lake. In the ecology of Lake Kainji: the transition from river to lake. University of Ife, Ife, Nigeria. $203 \mathrm{p}$.

Odum, E.P. 1971. Fundamentals of Ecology. W.B. Saunders, Philadephia, Pennsylvania, USA.

Olaniyan, C.I.O. 1975. West Africa animal ecology. Heinemann, London, England.

Olaosebikan, B.D. \& A. Raji.1998. Field guide to Nigerian Freshwater Fishes. Federal College of Freshwater Fisheries Technology, New Bussa, Nigeria.

Parks, R.W., E. Searbrook \& C.E. Boyd. 1975. Phytoplankton and water quality in a fertilized fish pond. Auburn University (Ala). Agr. Exp. Sta. Cir. 224: $16 \mathrm{p}$.

Reed, W., B. John, A.J. Hopson, J. Jonathan \& Y. Ibrahim. 1967. Fish and fisheries of Northern Nigeria. Ministry of Agriculture, Northern Nigeria.

Van Der Wall, B.C.W. \& H.J. Schoonbee. 1975. Age and growth studies of Clarias gariepinus in the Transvaal, South Africa. J. Fish. Biol. 7: 227-233.

Wetzel, R.G. 1975. Limnology. W.B. Saunders, Philadelphia, Pennsylvania, USA.

Willoughby, N.G. 1974. The ecology of the genus Synodontis (Pisces: Siluroidei) in lake Kainji, Nigeria. Ph.D. Thesis, University of Southampton, Southampton, England. 
